\title{
UMA PALAVRA E UMA ANTÍTESE: CONTRIBUIÇÃO À HISTÓRIA DO VERBO “LOGRAR”
}

\author{
José Américo Miranda* \\ Nilton de Paiva Pinto**
}

\begin{abstract}
Resumo: Este artigo discute, a partir de uma antítese presente num poema de Eusébio de Matos, os significados do verbo "lograr" no século XVII e em outras épocas. O problema a ser discutido surgiu durante os trabalhos de edição da obra A Paixão de Cristo Senhor Nosso, que contém o poema. O trabalho aborda o problema das alterações semânticas e apresenta uma sugestão à história da Língua Portuguesa.
\end{abstract}

Palavras-chave: Literatura Brasileira, Poesia Barroca, História da Lingua Portuguesa.

\section{Problema}

Os significados do verbo "lograr" constituem o objeto deste estudo. Nos trabalhos de edição da obra intitulada A Paixão de Cristo Senhor Nosso, de Eusébio de Matos, ${ }^{1}$ esse verbo ocorre em diversos manuscritos apógrafos como um dos termos de uma antítese. Um dos manuscritos, entretanto, apresenta outro verbo na mesma passagem - aparentemente com a finalidade de tornar mais clara a oposição das idéias. Atendendo ao princípio ecdótico da lectio difficilior - que consiste em dar preferência à lição mais difícil, para evitar a inteligibilidade facilitada do texto operada por copistas passou ao texto apurado o verbo "lograr": o sentido que ele tem na passagem em questão é corrente nos dias atuais, mas é contrário ao sentido de seu étimo e ao sentido mais encontrado em textos dos séculos XVI, XVII e XVIII.

O verbo "lograr" aparece no segundo poema da obra A Paixão de Cristo Senhor Nosso, ainda inédita, de Eusébio de Matos. Essa obra é constituída por um conjunto de poemas dedicados à paixão de Cristo, começando pela ceia da quinta-feira santa e terminando, depois da morte de Cristo, na soledade da Virgem. O poema de que aqui se trata é um romance dedicado ao tema da instituição da Eucaristia - o mesmo tema do primeiro poema do livro, um soneto.

A instituição da Eucaristia é abordada pelo poeta como resultado de duas forças contrárias: sabia Cristo que era chegada a hora, "era forçoso o partir" - e, no entanto, por amor aos homens, desejava ficar, buscava "traças para ficar". ${ }^{2}$ Com a instituição da

\footnotetext{
* José Américo Miranda: Professor Adjunto de Literatura Brasileira, Faculdade de Letras da UFMG, Doutor em Literatura Comparada. Endereço: Faculdade de Letras da UFMG. Av. Antônio Carlos, 6.627. Belo Horizonte. MG. CEP: 31.270-901.e-mail: bmaj@uol.com.br

${ }^{* *}$ Nilton de Paiva Pinto: Mestrando em Literatura Brasileira no Programa de Pós-Graduação em Letras Estudos Literários da Faculdade de Letras da UFMG. Endereço: Programa de Pós-Graduação em Letras Estudos Literários. Faculdade de Letras da UFMG. Av. Antônio Carlos, 6.627. Belo Horizonte. MG. CEP: 31.270-901. e-mail: ppnit@ig.com.br

${ }^{1}$ Os autores deste artigo estão preparando uma edição desta obra do poeta.

${ }^{2}$ MATOS, 1999, p.51.
} 
Eucaristia, Cristo "escusou o mal da ausência e aliviou o rigor da saudade". ${ }^{3}$ Portanto, o poeta vê a Eucaristia como a solução para o problema da concomitância do ficar e do partir - duas ações que, no plano humano, não podem coexistir.

Composto ao modo de cogitação, o romance "À Instituição do Santíssimo Sacramento na Ceia de Quinta-Feira Santa" é um discurso do poeta, feito em pensamento, dirigido diretamente a Deus. O poema se compõe de 15 quadras em versos octossílabos (pelo sistema atual de contagem silábica no verso português, setessílabos), com rimas toantes nos versos pares - como é de regra na forma romance. Sua quarta estrofe expõe claramente o dilema que alimenta a reflexão do poeta:

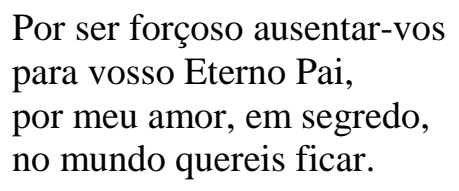

O confronto entre idéias contrárias perpassa todo o poema, podendo-se, mesmo, afirmar que a antítese é o fundamento ou o princípio de sua organização formal, sua figura estruturadora básica. Veja-se a estrofe seguinte, que, no romance, antecede à já citada:

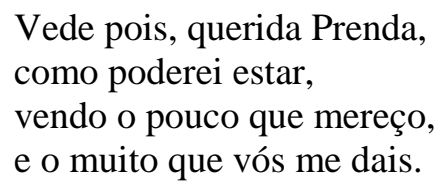

Nessa estrofe, os dois últimos versos se opõem, praticamente, termo a termo: "o pouco" se opõe a "o muito"; e a oração "que mereço" - que contém um "eu" e, implícito, um outro verbo, "receber" - se opõe à outra, que lhe é paralela no verso seguinte - "que vós me dais". Essas duas estruturas frasais são perfeitamente paralelas: "que [eu] mereço [receber de vós] / que vós me dais - primeira pessoa se opondo a segunda, e a idéia de receber contrariando a idéia de dar.

$\mathrm{Na}$ estrofe em que aparece o verbo "lograr", o último verso é antitético, pois apresenta duas idéias antagônicas. Um dos termos da antítese é o próprio verbo "lograr":

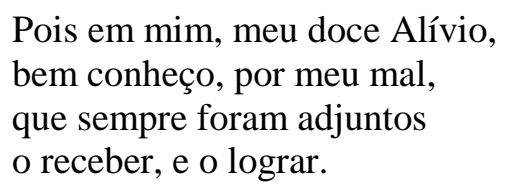

É claro o pensamento exposto na estrofe: o poeta reconhece, perante a divindade, que é de sua natureza ser pecador. Reconhece, também, que não sabe dar valor aos benefícios que recebe de Deus, pois freqüentemente o ofende. Sendo assim, o último verso da estrofe só pode apresentar idéias opostas - receber benefícios de Deus, e não merecer, pelos atos ofensivos que pratica, tais benefícios. Coube ao verbo "lograr" a expressão dessa última idéia: a ofensa a Deus está designada por esse verbo.

$\mathrm{Na}$ língua portuguesa, em seu estado atual, conhecemos bem o sentido que o verbo "lograr" tem nessa passagem. Entretanto, um dos copistas do poema registrou em seu lugar o verbo "largar", que se opõe muito mais claramente ao verbo "receber".

\footnotetext{
${ }^{3}$ MATOS, 1999, p.59.
} 
Desse fato, ou seja, da existência de um testemunho manuscrito do poema em que o verbo "largar" substitui "lograr", decorrem diversas indagações: poderia o verbo "lograr", no contexto do poema, opor-se a "receber"? a substituição de "lograr" por "largar" foi percebida como necessária ao sentido do verso por quê? até que ponto essa necessidade estaria relacionada aos sentidos que pode ter o aquele verbo (lograr)? e, caso o verbo tenha sofrido alteração de sentido, em que momento da história da língua ela teria ocorrido?

A obra de que estamos tratando, A Paixão de Cristo Senhor Nosso, possui quatro testemunhos apógrafos completos, todos eles em códices da obra de Gregório de Matos, de quem Eusébio de Matos era irmão. São eles: 1. o códice Asensio-Cunha, que hoje pertence à coleção Celso Cunha da Biblioteca da Universidade Federal do Rio de Janeiro (UFRJ) [aqui denominado A]; 2. o códice do cofre 50.1.11 (antigo 50,56), que pertenceu ao imperador D. Pedro II e hoje pertence à Biblioteca Nacional do Rio de Janeiro (BNRJ) [aqui denominado B]; 3. o códice Manuscrito $\mathrm{n}^{\circ}$ 587, do Fundo Manizola, que pertence à Biblioteca e Arquivo Distrital de Évora (BADE), Portugal [aqui denominado C]; e 4. o códice L.15-2, que pertenceu ao historiador Francisco Adolfo de Varnhagen e hoje pertence à Biblioteca do Itamarati (BI) [aqui denominado D]. Evidentemente, o romance dedicado à "Instituição do Santíssimo Sacramento na Ceia de Quinta-Feira Santa" aparece em todos esses manuscritos.

Alguns poemas dessa obra de Eusébio de Matos aparecem, também, em cinco outros manuscritos. A esses manuscritos chamaremos de incompletos, por não conterem toda a coleção que constitui a obra. Três deles trazem cópias do romance que apresenta o problema ora em estudo. São eles: 1. o manuscrito $n^{\circ} 46$ do Arquivo da Casa da Fronteira, da Torre do Tombo, em Lisboa, Portugal; 2. o manuscrito $\mathrm{n}^{\circ} 253$ da coleção dos Portuguese Manuscripts, da Library of Congress, de Washington, D.C., nos Estados Unidos da América; e 3. o manuscrito I - 7,12,32 da Biblioteca Nacional do Rio de Janeiro.

O exame dos manuscritos completos revelou que os testemunhos $\mathbf{B}, \mathbf{C}$ e $\mathbf{D}$ apresentam erros comuns importantes, que nos permitem agrupá-los numa só família. $\mathrm{O}$ testemunho A, que foi editado por James Amado sob o título de Crônica do Viver Baiano Seiscentista, pretensa reunião da obra completa de Gregório de Matos, foi escolhido pelo editor por ser de "leitura muito fácil", por ser "o único que está livre de erros, inclusive os de métrica, raríssimos", e por "manter perfeita unidade de pontuação". 4

$\mathrm{Na}$ edição dessa obra de Eusébio de Matos, procurou-se seguir o princípio da lectio difficilior, o que afastou a possibilidade de ser o manuscrito A o texto-base. Esse testemunho, dado por James Amado como o mais correto, o mais compreensível, o mais legível, o mais limpo é, justamente, o que traz o verbo "largar" no lugar do verbo "lograr" - tornando imediatamente apreensível a antítese que envolvia, como termo oposto, o verbo "receber".

Adotou-se, no procedimento da edição, um ponto de vista oposto ao de James Amado: enquanto ele optou pela facilidade com que os textos do testemunho A se ofereciam à compreensão e à leitura, preferiu-se o ponto de vista contrário, adotando como texto-base o manuscrito $\mathbf{B}$, o que mais dificuldades apresentava - tanto no que diz respeito à língua como no tocante à versificação e ao estilo. Nas palavras de Segismundo Spina: "Um manuscrito de linguagem clara, fluente, via de regra não é preferível a um manuscrito de linguagem obscura, pois é freqüente o caso de copistas

\footnotetext{
${ }^{4}$ AMADO, 1969, v.VII, p.1741.
} 
colocarem em linguagem inteligível aquilo que não entenderam no manuscrito copiado."5

Se tal princípio tem validade geral, muito mais há de ter no caso de uma obra poética barroca, estilo reconhecido pelas dificuldades que apresenta e pelas estruturas lingüísticas específicas da época em que ocorreu. Essa poética, a do "estilo culto", consistia, como afirmou Segismundo Spina a respeito de d. Francisco Manuel de Melo, um dos poetas do tempo, "numa linguagem e num jogo dialético retorcidos, sentenciosos, enigmáticos" e em "evitar a clareza das imagens e a transparência dos conceitos." Sendo assim, não é de estranhar que o barroco represente uma culminação do processo evolutivo em que, segundo expressão de Jorge Guillén, "a expressão indireta se desenvolveu até formar uma linguagem dentro da língua comum, a linguagem poética."7 Bastaria, para demonstrar tal fato a edição das Soledades, de Gôngora, preparada por Dâmaso Alonso em comemoração ao terceiro centenário da morte de seu autor. Nessa edição, ele, Dâmaso Alonso, por causa da dificuldade do texto, preparou, para cada estrofe do poema, uma "versão em prosa" para o próprio espanhol, língua em que os poemas foram originalmente escritos. ${ }^{8}$

Acrescente-se a esses argumentos o fato de não existir uma história do verso português que possa guiar o pesquisador de textos do século XVII com segurança. ${ }^{9}$ Rogério Chociay, um dos mais importantes teóricos do verso no Brasil, afirma que "na verdade os versos brasileiros e portugueses de todas as épocas não estão ainda esmiuçados em sua totalidade, e quando isto for feito muita coisa nova poderá vir à tona." 10

O manuscrito mais facilmente inteligível, A, que James Amado elegeu para editar Gregório de Matos, é justamente o que apresenta a variante "largar", no lugar do verbo "lograr", facilitando, assim, a compreensão e a inteligência da antítese cujo primeiro termo é constituído pelo verbo "receber". Ora, "receber" se opõe muito mais claramente a "largar" do que a "lograr". Entretanto, a possibilidade da oposição entre "receber" e "lograr" não pode ser desprezada - após reexame, ela se confirma. Esse seria um bom exemplo para o argumento apresentado por Antônio Houaiss a propósito do discernimento da boa lição: "se uma lição parece à primeira vista dar sentido falso, mas no fundo, após exame, dá sentido justo, deve ser preferida". ${ }^{11}$

\section{Discussão}

O que está em jogo é o sentido do verbo "lograr". Ele forma antítese com o verbo "receber" numa das estrofes do já mencionado poema de Eusébio de Matos. Num dos manuscritos, aquele que tem sido considerado o de mais fácil compreensão, o verbo foi substituído por outro - "largar". Com este verbo a antítese é muito clara, pois a idéia de "largar" encontra-se em campo semântico oposto ao da idéia de "receber".

A dificuldade surge quando se considera "lograr" como antítese de "receber", pois "lograr" vem do latim lucrare, que significa "ganhar, lucrar, adquirir, obter, conseguir" - e todas essas palavras partilham com "receber" o mesmo campo de significação; são palavras afins e não opostas pelo sentido.

\footnotetext{
${ }^{5}$ SPINA, 1994, p.73.

${ }^{6}$ SPINA, 1988, p.19.

${ }^{7}$ GUILLÉN, 1983, p.33-34.

${ }^{8}$ Cf. GÓNGORA, 1982.

${ }^{9}$ Cf. CUNHA, Celso, 1984, p.67-86.

${ }^{10}$ CHOCIAY, 1974, p.104.

${ }^{11}$ HOUAISS, 1967, v.I, p.248.
} 
Como já foi dito, na língua, em seu estado atual, é bem conhecido o sentido oposto ao de "receber", que o verbo "lograr" tem nessa antítese. Se um dos copistas do poema registrou em seu lugar o verbo "largar", que se opõe muito mais claramente ao verbo "receber", é certamente porque a substituição foi percebida como necessária ao sentido do verso. A pergunta é: já possuía, no século XVII, o verbo "lograr" um sentido oposto ao de "receber"?

Para realizar a investigação, foram percorridos dois caminhos: 1. o exame de algumas ocorrências do verbo "lograr" em obras literárias de épocas diversas; 2. o exame dos significados atribuídos a esse verbo nos mais importantes dicionários da língua, incluindo alguns dicionários etimológicos.

\subsection{Primeiro Caminho}

"Lograr" significa "obter, conseguir, alcançar, tirar lucro (de algo)", mas pode significar, também, "enganar, defraudar, intrujar, iludir", ou seja, "prejudicar, roubar" o primeiro campo semântico será chamado de positivo; o segundo, de negativo.

Uma consulta ao Vocabulário Histórico-Cronológico do Português Medieval, projetado e coordenado por Antônio Geraldo da Cunha, revelou que o verbo foi encontrado dezessete vezes em obras dos séculos XIV e XV e que, em todos os casos, o seu sentido pertence à área de positividade da significação da palavra. ${ }^{12}$

O poeta Luís de Camões, em Os Lusíadas, emprega o verbo nove vezes. ${ }^{13}$ Serão examinadas algumas dessas ocorrências. Uma delas está no canto terceiro, na oitava $\mathrm{n}^{\circ}$ 118, que introduz o episódio de Inês de Castro:

Passada esta tão próspera vitória,

Tornado Afonso à lusitana terra,

A se lograr da paz com tanta glória

Quanta soube ganhar na dura guerra,

O caso triste e dino da memória

Que do sepulcro os homens desenterra,

Aconteceu da mísera e mesquinha

Que despois de ser morta foi rainha. ${ }^{14}$ (Grifo nosso.)

Nessa passagem, como registram Evanildo Bechara e Segismundo Spina, a expressão "a se lograr da paz" significa "gozar dela; tirar proveito dela" ${ }^{15}$ Trata-se do campo positivo da significação do verbo "lograr". Seu sentido, aqui, está próximo da idéia de "lucrar", pois d. Afonso tira proveito da paz que alcançou.

Outra ocorrência do verbo está no quarto canto, na oitava $n^{\circ} 23$, que narra parte da trajetória de D. João I:

Com tôda esta lustrosa companhia Joane forte sai da fresca Abrantes, Abrantes, que também da fonte fria Do Tejo logra as águas abundantes. ${ }^{16}$ (Grifo nosso.)

\footnotetext{
${ }^{12}$ Cf. CUNHA, Antônio Geraldo da, 2002.

${ }^{13}$ Cf. CUNHA, Antônio Geraldo da, 1980.

${ }^{14}$ CAMÕES, s.d., p.308.

${ }^{15}$ BECHARA, SPINA, 1973, p.144.

${ }^{16}$ CAMÕES, s.d., p.342.
} 
O que aí diz o poeta é que a cidade de Abrantes lucra com as águas do Tejo, ou seja, beneficia-se delas. O verbo está, portanto, na mesma esfera semântica da positividade, que é a da idéia de benefício e de lucro.

Ainda outra passagem com o verbo "lograr" ocorre no quinto canto, na oitava $\mathrm{n}^{\circ}$ 10, que é parte da narrativa da navegação de Vasco da Gama pela costa africana e antecede o episódio do gigante Adamastor,

Por aqui rodeando a larga parte

De África, que ficava ao Oriente:

A província Jalofo, que reparte

Por diversas nações a negra gente,

A mui grande Mandinga, por cuja arte

Logramos o metal rico e luzente,

Que do curvo Gambeia as águas bebe,

As quais o largo Atlântico recebe;

As Dórcadas passámos, povoadas

Das irmãs que outro tempo ali viviam,

Que, de vista total sendo privadas,

Tôdas três dum só ôlho se serviam. ${ }^{17}$ (Grifo nosso.)

Silveira Bueno informa que Mandinga era reino muito rico em ouro ${ }^{18}-$ donde o verso "logramos o metal rico e luzente" significar "conseguimos, ou obtivemos, o ouro". Como se vê, trata-se da idéia de ganho, lucro.

Por fim, um último exemplo, do nono canto, oitava $\mathrm{n}^{\circ}$ 87, em pleno episódio da Ilha dos Amores:

Tomando-o pela mão, o leva e guia

Para o cume dum monte alto e divino,

No qual ũa rica fábrica se erguia,

De cristal tôda e de ouro puro e fino.

A maior parte aqui passam do dia,

Em doces jogos e em prazer contino.

Ela nos paços logra seus amores,

As outras pelas sombras, entre as flores. ${ }^{19}$ (Grifo nosso.)

"Ela", Tétis, deusa do mar, "goza" ou "ganha" ou "obtém" os amores do Gama nos paços de seu palácio ("fábrica"). As outras ninfas "logram" seus amores entre as flores, com os outros marinheiros.

Já no século XVII, eis um exemplo tomado ao "Soneto XIV - Anel de Anarda Ponderado", da Música do Parnasso, de Manuel Botelho de Oliveira:

Esse vínculo, Anarda, luminoso,

Do mínimo jasmim prisão dourada,

Logra na mão beleza duplicada,

Quando logra na mão candor fermoso. ${ }^{20}$ (Grifo nosso.)

\footnotetext{
${ }^{17}$ CAMÕES, s.d., p.394.

${ }^{18}$ Cf. CAMÕES, s.d., p.394.

${ }^{19}$ CAMÕES, s.d., p.663.

${ }^{20}$ OLIVEIRA, 1953, t.I, p.21.
} 
Em meio a metáforas cultas, como "vínculo luminoso", para dizer anel, e "mínimo jasmim" para dizer dedo, afirma o poeta que o anel "alcança, consegue, obtém, goza" beleza duplicada ao "lograr" pureza ou inocência juntamente com limpidez e alvura.

Ainda do mesmo poeta, o "Romance I - Anarda Passando o Tejo em Uma Barca" assim se refere à entrada do rio no mar:

Já deixa o nome de rio,

Oceano se assegura,

Pois a branca Tétis logra,

Pois o claro sol oculta. ${ }^{21}$ (Grifo nosso.)

O rio "alcança Tétis" - o nome da ninfa é metonímia de oceano. A linguagem figurada sugere, evidentemente, que "lograr Tétis" é motivo de prazer para o rio, ou seja, ele "goza, usufrui, etc."

Em todos esses casos, o verbo apresenta as conotações aqui chamadas de positivas - por se situarem na esfera da idéia de "lucro", sentido primeiro da palavra.

O verbo "lograr" apareceu na língua escrita já no século XIII. ${ }^{22}$ José Pedro Machado assinala a presença do verbo, no século XIII, numa das cantigas de Afonso X, o Sábio, no Cancioneiro da Biblioteca Nacional. ${ }^{23} \mathrm{O}$ texto de Camões é do século XVI e o de Botelho de Oliveira do século XVII. Já o verbo lucrar, de recuperação erudita, só aparecerá mais tarde, no século XVII ${ }^{24}$ ou XVIII. ${ }^{25}$

A dúvida, então, é a seguinte: poderia o verbo "lograr", no século XVII, ser um termo antitético em relação ao verbo "receber"? Os sentidos de "lucrar, alcançar, conseguir, obter, ganhar, adquirir, usufruir, gozar, aproveitar-se de" pertencem todos ao campo semântico do verbo "receber" e jamais poderiam formar com ele um par antitético.

Entretanto, na atualidade, o verbo "lograr" leva, em primeiro lugar, os sentidos de "enganar; defraudar, iludir" - sentidos esses que podem se opor ao sentido de "receber", porque o que se recebe é "ganho, benefício", e o que se consegue enganando, ludibriando, é "furto, roubo, subtração".

Em textos literários, o verbo "lograr" ocorre com esse segundo sentido (oposto ao primeiro), já no século XIX, numa nota de rodapé, na obra As Virtudes Antigas ou A Freira que Fazia Chagas e o Frade que Fazia Reis, de Camilo Castelo Branco. Eis a nota:

Propendemos a crer que os três mouros eram uns velhacazes e farçantes maiores da conta, ajustados a lograrem o provincial, sem receio de que o seu Mafoma os castigasse pela tramoia. O segundo acto da farçada consistiu em se deixarem ficar no mosteiro comendo à tripa fôrra. $\mathrm{O}$ terceiro, e mais espectaculoso devia ser o embaraço dos mouros convertidos quando, passados três anos, a freira foi condenada por impostura. É bem de entender que o provincial atribuíu a influïção diabólica aquêle ir de borco ao chão, quando Jesus Cristo se mostrou humanalmente aos mouros, ombro a ombro da prioresa. ${ }^{26}$ (Grifo nosso.)

\footnotetext{
${ }^{21}$ OLIVEIRA, 1953, t.I, p.51.

${ }^{22}$ Cf. CUNHA, Antônio Geraldo da, 1982.

${ }^{23}$ MACHADO, 1987, v.III, p.438.

${ }^{24}$ Cf. CUNHA, Antônio Geraldo da, 1982.

${ }^{25}$ Cf. HOUAISS, 2001.

${ }^{26}$ CASTELO BRANCO, 1943, p.65.
} 
Vê-se aí o verbo "lograr" empregado no sentido de "enganar, defraudar, iludir" bem capaz de compor uma antítese com o verbo "receber", pois os mouros enganaram o provincial, isto é, o lograram, para receber dele um favor, fartar-se nas mesas do convento. Enquanto o provincial lhes fazia um bem, eles lhe faziam um mal, pois o enganavam. Essa esfera da significação do verbo "lograr", oposta à primeira, corresponde ao campo "negativo" do termo.

Autor brasileiro do mesmo século de Camilo Castelo Branco que emprega esse verbo com a acepção negativa é Martins Pena, na comédia $O$ Cigano - numa cena em que o Cigano conversa com o comerciante Tomé, que tem a pretensão de casar-se com sua filha e manifesta-lhe o receio de que seus negros os denunciem pelos roubos que praticam para eles. Eis um pequeno trecho do diálogo:

CIGANO - É preciso cuidado. Esses negros podem um dia denunciar-nos. TOMÉ - Qual, não penses nisto; a cachaça fecha-lhes a boca. Tenho cá a minha companhia muito bem organizada. Todos os dias pela manhã vão lá à minha venda doze negros de ganho e eu dou a cada um deles um copinho da branca e lhes digo: "Meus filhos, quando te chamarem para carregar alguma carga, logra a pessoa que te acompanhar ao voltar alguma esquina e traze tudo à venda, que te darei outro copinho e alguns cobres em cima." ${ }^{, 27}$ (Grifo nosso.)

Eles, Tomé e o Cigano, encarregavam os negros de trazerem de volta as mercadorias vendidas a seus fregueses, passando-lhes a perna, enganando-os, lograndoos. Portanto, o verbo "lograr" aparece aqui no campo da negatividade.

Outro autor brasileiro da mesma época empregou não o verbo "lograr", mas o substantivo "logro", que pertence à mesma família léxica. Trata-se de Álvares de Azevedo, na obra Macário. O personagem principal, em diálogo com um desconhecido, diz: "Duvido sempre. Descreio às vezes. Parece-me que este mundo é um logro. O amor, a glória, a virgindade, tudo é uma ilusão." ${ }^{28}$ (Grifo nosso.) Como se vê, nessa passagem "logro" é sinônimo de ilusão, engano - idéia que se associa à idéia de perda e, portanto, à esfera da negatividade.

No século XX, Carlos Drummond de Andrade, traduzindo Molière, empregou o verbo no sentido moderno de "enganar, passar a perna, etc." Em Les Fourberies de Scapin, as palavras do personagem Argante - Vous vous êtes donc accordés, coquin; vous vous êtes accordés, Scapin, vous et mon fils, pour me fourber, et vous croyez que je l'endure? ${ }^{29}$ - ganharam a seguinte tradução de Drummond: "Com que então, seu malandro, você, Scapino e meu filho se juntaram para me lograr, hein? E pensam que vou tolerar uma coisas dessas?"30 (Grifo nosso.) A repreensão feita a Scapino deve-se ao fato de ele, Scapino, associado ao filho de Argante, o estar enganando (a Argante).

Paulo Rónai, em sua biografia de Balzac, indagava, empregando o verbo nessa mesma acepção: "Como era possível que ele [Balzac] que, em seus romances, sabia, conhecia, observava e penetrava tudo, na vida era sempre enganado, logrado?"31 (Grifo nosso.)

\footnotetext{
${ }^{27}$ PENA, 1956, p.346-347.

${ }^{28}$ AZEVEDO, 1965, p.171.

${ }^{29}$ MOLIÈRE, 1972, p.105.

${ }^{30}$ MOLIÈRE, 1962, p.81.

${ }^{31}$ RÓNAI, s.d., p.116.
} 


\subsection{Segundo Caminho}

O exame das significações do verbo "lograr" resultou na distinção de dois campos semânticos opostos: por um lado, a palavra significa "ganhar, obter, alcançar, usufruir, gozar"; por outro, significa "enganar, passar a perna, prejudicar" - idéias estas que introduzem, de algum modo, no campo das relações entre "ganhar e perder" o ponto de vista do perdedor.

Quanto aos dicionários atuais da língua, serão examinados apenas três. No dicionário de Antônio Houaiss encontram-se as seguintes significações para o verbo "lograr": 1. conseguir, alcançar (algo); obter (algo) a que se tem direito ou que se deseja; 2. usufruir (algo) que se conquistou; gozar, desfrutar; 3. tirar proveito ou satisfação; aproveitar(-se); 4. surtir efeito, ter o resultado esperado; 5. enganar (alguém) através de artimanhas; iludir, burlar. ${ }^{32} \mathrm{O}$ de Aurélio Buarque de Holanda Ferreira traz: 1. gozar; obter; fruir, desfrutar, desfruir; 2. tirar lucro de; aproveitar. 3. conseguir, alcançar, 4. enganar com astúcia; burlar, intrujar, defraudar. ${ }^{33}$ Caldas Aulete registra: 1. gozar, obter; 2. fruir, desfrutar; 3. possuir; 4. aproveitar, tirar lucro de; 5. enganar com astúcia ou manha, ou por gracejo; burlar. ${ }^{34}$

Observe-se que todos eles dão prioridade ao sentido "positivo" da palavra, que confina com as idéias de "lucro, ganho, proveito, benefício, fruição, usufruto, gozo, etc." Em todos esses casos, o foco da atenção está no beneficiário da ação. Somente ao final dos verbetes aparece o sentido "negativo", aparentado à idéia de "enganar, passar a perna em alguém", que põe em jogo o interesse da parte que perde na ação, ou seja, põe no horizonte do entendimento do falante a perspectiva do "prejuízo," da "perda" - idéia contrária à anterior.

Como foi visto, o verbo "lograr" apareceu na língua escrita já no século XIII. O verbo lucrar, por sua vez, resultou de recuperação erudita, por retorno ao étimo latino, e só aparece no século XVII, segundo Antônio Geraldo da Cunha; no século XVIII, segundo Antônio Houaiss.

Para "lucrar", Aurélio Buarque de Holanda Ferreira consigna: 1. tirar vantagem de, aproveitar; 2. gozar, desfrutar; 3. conseguir, lograr; 4. produzir, render; 5. obter lucro, ganhar; 6. tirar lucros, vantagens; adquirir proveito. Antônio Houaiss registra: 1. obter (alguma coisa), beneficiar-se, ganhar; 2. obter, atingir, colher (algo prazeroso), desfrutar, gozar, conseguir, alcançar, lograr; 3. auferir ganhos (em operações comerciais ou atividade econômica), ganhar. Caldas Aulete, por sua vez, registra: 1. ganhar, interessar, tirar lucros; 2. gozar, desfrutar, aproveitar, tirar vantagem. Como se vê, os verbetes dos dicionários atuais registram para "lucrar" apenas os sentidos positivos de "lograr".

Os dicionários etimológicos apontam o verbo depoente latino lucror, aris, atus sum, ari, como o étimo de "lograr" ${ }^{35}$ Curioso é o verbete do Novo Dicionário Etimológico da Língua Portuguesa, de Rodrigo Fontinha, revisto pelo dr. Joaquim Ferreira, editado no Porto. Nesse dicionário, além de não apontar o étimo do verbo "lograr", as significações positiva e negativa do vocábulo aparecem em ordem inversa, isto é, as acepções impregnadas de negatividade antecedem às outras: 1. enganar, defraudar, intrujar, iludir; 2. gozar; desfrutar; usufruir; alcançar; 3. aproveitar-se ou tirar proveito ${ }^{36}$ A pergunta que cabe aqui é esta: estariam os sentidos em ordem inversa com

\footnotetext{
${ }^{32}$ Cf. HOUAISS, 2001.

${ }^{33}$ Cf. FERREIRA, 1999.

${ }^{34}$ Cf. AULETE, 1958.

${ }^{35}$ Cf. CUNHA, Antônio Geraldo da, 1982; BUENO, 1966; HOUAISS, 2001.

${ }^{36}$ Cf. FONTINHA, s.d.
} 
relação à da maioria dos outros dicionários por efeito da significação da palavra nos usos que dela modernamente se fazem?

\subsection{Hipóteses}

Esse conjunto de informações faz retornarem as perguntas originais: poderia o verbo "lograr" opor-se a "receber"? a substituição de "lograr" por "largar" foi percebida como necessária ao sentido do verso por quê? até que ponto essa necessidade está relacionada aos sentidos que pode ter o verbo "lograr"? e, caso o verbo tenha sofrido alteração de sentido, em que momento da história da língua ela teria ocorrido?

Bem sabemos que a imobilidade na língua não existe, que "todas as partes da língua estão submetidas à mudança." ${ }^{37}$ Mudam os sons das palavras ao longo do tempo, mudam as estruturas sintáticas da língua, mudam os sentidos das palavras. Interessanos, aqui, sobretudo este último aspecto - o das mudanças de significação de uma palavra.

Como surgem e desaparecem, as palavras evoluem de diversas maneiras. Muitas vezes se conservam iguais a si mesmas no plano significante, mas alteram-se profundamente quanto ao significado. "As diversas mudanças de sentido que sofrem as palavras, se reduzem, em algumas ocasiões, a três tipos principais: restrição, extensão e deslocamento." ${ }^{38}$

$\mathrm{Na}$ restrição de sentido passa-se de um sentido geral a outro particular. É o que ocorreu com o verbo latino ordinare, que, na língua geral significava "pôr ordem" ou "ordenar". Esse mesmo verbo - ordenar - "passou à linguagem técnica dos criadores de gado, vaqueiros, leiteiros, no sentido de colocar em ordem a situação das vacas leiteiras quando o úbere estava excessivamente cheio, portanto, fora do normal, diminuindo-lhe o excesso de leite pela ordenha." ${ }^{39}$ M. Said Ali nos dá os seguintes exemplos: "Sermão aplica-se hoje a um discurso de caráter muito especial, posto que o latim sermo significasse linguagem em geral. Padre, que tanto podia exprimir o pai carnal como o pai espiritual ou sacerdote, conserva hoje somente o sentido translato." "Nesses casos, houve também alteração fonética, pois ordinare tornou-se "ordenhar", "sermão" deriva de sermo e "padre" provém de pater.

Mas há casos em que a palavra altera-se apenas no plano da significação. Said Ali nos dá como exemplo as palavras "polícia" e "político". Explica ele:

Político dizia outrora o mesmo que hoje o termo civilizado; e polícia significava civilização, progresso, estado adiantado, tratamento fino, etc. [...] Polícia se dizia tanto do estado adiantado de um povo, comparado com a barbárie de outros, como também do progresso manifestado nos edifícios e nos produtos e utensílios. [...] Polícia designa hoje a força pública que mantém as leis, a ordem, a segurança. É denominação importada de França. O uso intenso, aí e em Inglaterra, de um termo filiado ao latim politicus para cousas referentes ao governo do Estado, deu modernamente lugar à entrada de político, política, para o mesmo efeito, em língua portuguesa. ${ }^{41}$

Para exemplo de extensão do sentido há a palavra "calamidade", sobre a qual discorreu João Ribeiro do seguinte modo:

\footnotetext{
${ }^{37}$ SAUSSURE, s.d., p.163.

${ }^{38}$ VENDRYES, 1958, p.232.

${ }^{39}$ BUENO, 1963.

${ }^{40}$ ALI, 1951, p.82.

${ }^{41}$ ALI, 1951, p.99-101.
} 
Era primitivamente um termo da agricultura. Cálamo é o caniço, a cana ou talo do trigo. Sucedia por vezes cair nos campos forte granizo que quebrava os talos dos trigais. Para o lavrador era a calamidade, a destruição da seara.

Essa praga do campo e da agricultura passou à cidade e ao sentido comum de infortúnio ou desgraça geral.

Ninguém se lembraria dos cálamos que foram as primeiras vítimas da intempérie. $^{42}$

Por fim, para exemplo de deslocamento de sentido considere-se o próprio verbo "lograr". Há na língua palavras que designam simultaneamente uma coisa e seu contrário. Pode-se citar como exemplo o verbo "relevar", que significa "fazer sobressair, salientar, dar destaque ou relevo", mas pode significar, também, "atenuar". Outra palavra semelhante é "confusão", que pode significar "tumulto, barulho, barafunda", mas pode significar, também, "perturbação causada pela modéstia, pelo pudor, pela vergonha de alguma falta", ou seja, "embaraço moral ou psicológico" idéias essas que confinam com as idéias de recolhimento e silêncio. E a palavra "sorte" pode significar "azar, má sorte".

O verbo "lograr", em sua acepção positiva, significa "lucrar". Designa, portanto, uma parte de algo que é mais abrangente: a relação em que alguém ganha alguma coisa, lucra, e alguém perde, fica no prejuízo.

A situação a que se referem "lograr" e "lucrar" é mais ampla do que a noção designada por esses vocábulos: não é possível pensar em "lucro" sem que esteja implícito no horizonte dessa idéia o seu contrário - prejuízo. Se alguém ganha, alguém perde. O senso dialético de um poeta como Carlos Drummond de Andrade o levou a exprimir sua percepção da existência individual num verso como o seguinte:

\section{Ganhei (perdi) meu dia. ${ }^{43}$}

Esse é um verso detentor da característica fundamental dos bons versos, que os torna como que uma grande palavra ou unidade de sentido. Nele, como em algumas palavras, coexistem os contrários. A possibilidade de convivência de dois sentidos contrários numa mesma palavra, já se viu que ocorre na linguagem.

Num artigo escrito em 1910, intitulado "A significação antitética das palavras primitivas", Sigmund Freud afirma ser essa uma "peculiaridade das línguas mais antigas que conhecemos." ${ }^{44}$ Freud chegou a formular esse pensamento a partir de um artigo publicado pelo filólogo alemão Karl Abel em 1884. A propósito da língua egípcia, diznos este autor: "Atualmente na língua egípcia, esta relíquia única de um mundo primitivo, há um bom número de palavras com duas significações, uma das quais é o oposto exato da outra." ${ }^{45}$ A diferença entre essa e outras línguas antigas, como a língua semita e o indo-europeu, e as línguas modernas é assim explicada por Freud (e Abel):

Segundo Abel é nas 'raízes mais antigas' que se vê ocorrerem as significações duplas antitéticas. No curso subseqüente do desenvolvimento da linguagem esta ambigüidade desapareceu e, no Antigo Egito, pelo menos, todos os estágios intermediários se podem acompanhar, até a não-

\footnotetext{
${ }^{42}$ RIBEIRO, 1963, p.24-25.

${ }^{43}$ ANDRADE, 1967, p.286.

${ }^{44}$ FREUD, 1970, v.IX, p.142.

${ }^{45}$ Apud FREUD, v.IX, p.142.
} 
ambigüidade dos vocabulários modernos. [...] ...conceitos a que só se poderia chegar por meio de uma antítese tornaram-se, no curso do tempo, suficientemente familiares às mentes dos homens, possibilitando uma existência independente, para cada uma de suas duas partes, e, em consequiência, permitindo a formação de um representante fonético separado para cada parte. ${ }^{46}$

Que tal fenômeno de ambigüidade ou de antítese subsiste nas línguas modernas, inclusive a nossa, já se exemplificou. O próprio verbo "lograr", de algum modo, comporta sentidos contraditórios, pois designa o "ganhar", mas, principalmente na atualidade, insinua o prejuízo correlato do lucro ao expressar as idéias de "enganar, defraudar, iludir, prejudicar".

Segundo o raciocínio feito por Freud e Karl Abel, as diferenças no modo de designar as idéias ou as coisas se devem a estágios evolutivos da civilização: seria característica do pensamento primitivo o uso das palavras antitéticas, ao passo que seria próprio do homem moderno ou das civilizações avançadas o pensar analiticamente, designando como se fossem autônomas as partes de um todo.

A explicação para essas diferenças, entretanto, não é necessariamente essa. $\mathrm{O}$ pensamento antitético não é necessariamente primitivo: ele é, sim, uma das formas possíveis do pensamento humano, e não das mais desinteressantes ou toscas - pelo contrário, é uma forma muito refinada de exercício mental. Yu-Kuang Chu, especialista em estudos interculturais que envolvem a América do Norte e o Extremo Oriente, para caracterizar as línguas faladas nessas regiões, refere-se a "duas séries algo diferentes de processos mentais e de hábitos conceituais." ${ }^{47}$ Segundo esse autor, a reflexão relacional "tem sido uma qualidade distintiva do pensamento e da cultura chineses." estrutura frasal chinesa, pelo fato de um mesmo signo poder, quando isolado, ter diversas significações e pelo fato de um mesmo signo poder desempenhar na frase papéis gramaticais os mais diversos, em cada ocorrência de um vocábulo o seu sentido depende das relações e do arranjo estrutural em que ele se encontra. A atividade interpretativa, portanto, repousa sobre uma lógica de relações. ${ }^{49}$

Ainda sobre esse tema, diz o autor:
A ênfase dada às relações entre as palavras tem provavelmente muito a ver com o pensamento relacional manifestado em numerosas áreas da vida e da cultura chinesas. Alguns exemplos serão suficientes. A arte e a arquitetura chinesas se caracterizam por uma acentuada noção de equilíbrio. A atenção se volta menos para os elementos separados que para a configuração total. As idéias são muitas vezes denotadas por expressões compostas, constituídas de antônimos; por exemplo: "comprar-vender" é "comerciar"; "avanço-recuo" é "movimento"; "norma-caos" é "condição política", etc. Os antônimos não são tidos como opostos irreconciliáveis, mas sim como suscetíveis de união para formar uma idéia completa. Um dos conceitos-chave da filosofia chinesa se expressa através de um composto de antônimos, yin, yang. ${ }^{50}$

Como se vê, o modo de pensar que dá ênfase à totalidade não está necessariamente vinculado ou restrito a línguas primitivas, mas corresponde a certas

\footnotetext{
${ }^{46}$ FREUD, 1970, v. IX, p.144.

${ }^{47}$ CHU, 1977, p.233.

${ }^{48}$ CHU, 1977, p.242.

${ }^{49}$ Cf. CHU, 1977, p.231-262.

${ }^{50}$ CHU, 1977, p.244-245.
} 
formas de pensamento. $\mathrm{O}$ chinês parece privilegiar esse modo de pensar, ao passo que as línguas ocidentais privilegiam o pensamento analítico, que decompõe o todo em partes, nomeando-as separadamente.

Num esquema visual, a situação, em termos de relações humanas, de que a noção designada pelo verbo "lograr" é parte, pode ser assim representada:

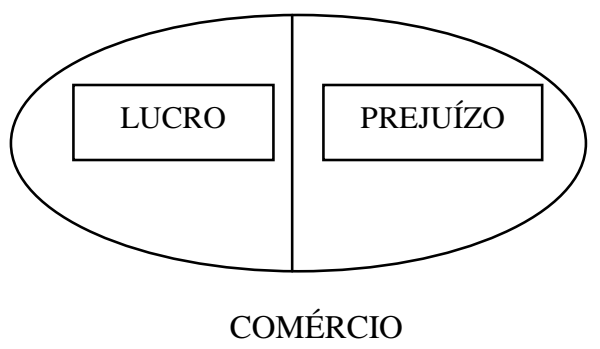

RELAÇÕES ENTRE PESSOAS

Nessa relação, o sentido positivo de "lograr" equivale, no esquema, ao campo recoberto pela idéia de "lucro". Designado em separado, esse campo passa a existir como que isoladamente, independentemente da parte negativa. $\mathrm{Na}$ história do verbo "lograr", constatou-se que ele recobria o campo da positividade em todas as suas ocorrências em textos medievais e do século XVI. Nos séculos XVII e XVIII é extremamente fácil encontrar a palavra nessa acepção.

Já no século XIX, textos de Álvares de Azevedo, Martins Pena e Camilo Castelo Branco testemunham que o verbo assume o campo negativo dessa estrutura relacional, ou seja, passa a expressar o prejuízo daquele que, na relação, sai lesado. No século XX a significação negativa da palavra é testemunhada por textos de Carlos Drummond de Andrade e de Paulo Rónai.

Os verbetes dos dicionários - com a curiosa exceção do Novo Dicionário Etimológico da Língua Portuguesa, de Rodrigo Fontinha - parecem dispor as significações numa ordem equivalente à dos sentidos que a palavra assumiu ao longo do tempo, figurando, no final das listas, os sentidos negativos, de introdução mais recente.

Uma palavra de introdução recente nos dicionários, provavelmente usada vulgarmente há muito, e que não consta do Vocabulário Ortográfico da Língua Portuguesa, na edição de 1999 - mas já consignada nos dicionários de Antônio Houaiss e no Aurélio Século XXI (edição eletrônica) é o substantivo feminino "roubada". Aurélio Buarque de Holanda registra para essa palavra os significados de "mau negócio, logro." Mau negócio é o que dá prejuízo. Em outras palavras, entrar numa roubada significa ficar no prejuízo. No Dicionário Houaiss da Língua Portuguesa o sentido atribuído ao termo é ainda precário, discreto, hesitante, distante do uso franco e de significação clara, como se vê neste trecho de Elio Gaspari:

Em 1971, Gabeira estava em Cuba, fazendo treinamento militar de guerrilheiro. Deu-se conta de que aquilo era uma roubada intelectual, sumiu da paisagem e reapareceu numa militância democrática no Chile e, depois, na Europa. Regressou em 1979, com a anistia. ${ }^{51}$ (Grifo nosso.)

${ }^{51}$ GASPARI, 2003. 
O Dicionário Houaiss diz que "roubada" é brasileirismo informal, melhor que "furada", termo que significa "o que frustra, não corresponde às expectativas, não dá certo ou acarreta prejuízo, aborrecimento, etc.". Ora, no trecho citado, "roubada" significa "logro, engano" - embora a idéia de "frustração" esteja também presente.

O próprio sentido negativo de "lograr" encontra-se registrado dubitativamente nos dicionários. Aurélio Buarque de Holanda consigna os sentidos de "enganar com astúcia, burlar" - o que implica as noções de brincadeira, gracejo, comicidade. Enfim, a designação do prejuízo causado pela ação de "lograr" vem contaminada de noções atenuadoras - ou seja, a definição apresentada pelo dicionário é eufemística.

Antônio Houaiss explica mais precisamente o sentido do verbo na fala popular. Diz ele que nesse uso de "lograr a noção de 'ganhar, obter vantagem' desloca-se do agente para o meio ou instrumento de enganar o paciente a fim de tirar proveito; $o$ significado nuclear torna-se 'enganar para roubar, usar de ardis para ganhar'., deslocamento da ênfase para o instrumento de que fala o lexicógrafo parece justificado pela freqüência com que o verbo se associou a atos cômicos e à própria comédia. Repare-se que o uso do verbo pelo poeta Carlos Dummond de Andrade ocorreu justamente na tradução de uma comédia e para verter para o português o verbo francês fourber, relacionado, em nossa língua, ao adjetivo furbesco, que significa "velhaco, patife".

Como a evolução das línguas não cessa, pode-se dizer que o verbo "lograr", na fala do povo, já deslocou a ênfase para além do "meio ou instrumento", para dar expressão plena ao prejuízo em que fica a parte lesada no tipo de relação humana em que alguém lucra.

Retomando a seqüência histórica das ocorrências do verbo "lograr", resta por observar a admissão à língua, por via erudita, no século XVII ou XVIII, do verbo "lucrar". Esse fenômeno de recuperação erudita de palavra equivalente a outra já existente na língua parece vir em conformidade com a seguinte observação de Said Ali: "Alteração de uma espécie anda quase sempre ligada a uma ou mais alterações de espécie diferente. O domínio semântico de um termo aumenta ou diminui com a perda ou lucro do domínio de outro termo." ${ }^{53}$ Comentando as alterações semânticas do verbo "afogar" ao longo da história da língua portuguesa, ele observa que este vocábulo já teve sentido mais lato do que o que tem hoje. A palavra referia-se a qualquer forma de asfixia, mas teve seu sentido restringido ao de asfixia por imersão em líquido, o que entendemos hoje por afogamento. "Foi o estrangeirismo sufocar, e não o eruditismo moderníssimo asfixiar, que veio substituir o antigo verbo na função de exprimir o afogamento a seco." 54

Ao que tudo indica, o verbo "lograr", já no século XVII comportava a idéia oposta à idéia de "lucro" e, portanto, podia compor antítese com o verbo "receber" como no verso de Eusébio de Matos. Como se sabe, e como diz Guiraud, "criamos as palavras para dar nomes às coisas, seja porque ainda não o têm, seja porque o que têm não cumpre mais eficazmente a sua função." 55 No século XVIII, muito provavelmente, o sentido de "lograr" já era suficientemente ambíguo para exigir que a idéia em seu sentido positivo passasse a ser designada por outro termo - questão que se resolveu historicamente com a recuperação erudita de "lucrar". E é de crer que, no século XVII, o verbo já pudesse, na língua vulgar, dar expressão plena ao campo negativo que a

\footnotetext{
${ }^{52}$ HOUAISS, 2001

${ }^{53}$ ALI, 1951, p.81.

${ }^{54}$ ALI, 1951, p.83.

${ }^{55}$ GUIRAUD, 1992, p.43.
} 
palavra vem progressivamente assumindo. Talvez o texto de Eusébio de Matos seja o mais antigo registro escrito desse verbo nesta acepção.

\section{Referências Bibliográficas}

ALI, M. Said. Meios de expressão e alterações semânticas. 2.ed. rev. Rio de Janeiro: Simões, 1951.

AMADO, James. Notas à margem da editoração do texto - II. In: MATOS, Gregório de. Crônica do viver baiano seiscentista. Bahia: Janaína, 1969. v.VII. p.1738-1743.

ANDRADE, Carlos Drummond de. Elegia. In: Obra completa. 2.ed. Rio de Janeiro: José Aguilar, 1967.

AULETE, Caldas. Dicionário contemporâneo da língua portuguesa. 4.ed. Rio de Janeiro: Delta, 1958. 5v.

AZEVEDO, Álvares de. Macário. In: Noite na taverna; Macário. São Paulo: Martins, 1965. p.143-258.

BECHARA, Evanildo, SPINA, Segismundo. (Orgs). Luís de Camões: Os lusíadas antologia. Rio de Janeiro: Grifo, 1983.

BUENO, Francisco da Silveira. Grande dicionário etimológico-prosódico da língua portuguesa. São Paulo: Saraiva, 1966. 8v.

CAMÕES Luís de. Os lusíadas. Ed. crítica de Francisco da Silveira Bueno. Rio de Janeiro: Edições de Ouro, s.d.

CASTELO BRANCO, Camilo. As virtudes antigas ou A freira que fazia chagas e $O$ frade que fazia reis / Um poeta portugues... rico. 4. ed. Lisboa: Parceria António Maria Pereira, 1943. Nota 1, p. 65.

CHOCIAY, Rogério. Teoria do verso. São Paulo: McGraw-Hill do Brasil, 1974.

CHU, Yu-Kung. Interação entre linguagem e pensamento em chinês. In: CAMPOS, Haroldo de.(Org). São Paulo: Cultrix, 1977. p.2

CUNHA, Antônio Geraldo da. Dicionário etimológico Nova Fronteira da língua portuguesa. $2^{\mathrm{a}}$ reimpr. Rio de Janeiro: Nova Fronteira, 1982.

CUNHA, Antônio Geraldo da. Índice analítico do vocabulário de Os lusíadas. 2.ed. Rio de Janeiro: Presença, 1980.

CUNHA, Antônio Geraldo da. (Org. e Proj.) Vocabulário histórico-cronológico do português medieval. Rio de Janeiro: Fundação Casa de Rui Barbosa, 2002. [Versão 1.0, edição eletrônica.]

CUNHA, Celso. A linguagem poética portuguesa na primeira metade do século XVI: hiato, sinalefa e elisão nas églogas de Bernardim Ribeiro e no Crisfal. In: Língua e verso. 3.ed. Lisboa: Sá da Costa, 1984.

FERREIRA, Aurélio Buarque de Holanda. Novo dicionário Aurélio da língua portuguesa. 2.ed. Rio de Janeiro: Nova Fronteira, 1986.

FERREIRA, Aurélio Buarque de Holanda. Dicionário Aurélio eletrônico - Século XXI. Rio de Janeiro: Nova Fronteira/Lexikon Informática, 1999. [Versão 3.0, edição eletrônica.]

FREUD, Sigmund. Cinco lições de psicanálise; Leonardo da Vinci e outros trabalhos. Rio de Janeiro: Imago, 1976. v. XI. [Edição Standard Brasileira das Obras Psicológicas Completas de Sigmund Freud.]

FONTINHA, Rodrigo. Novo dicionário etimológico da língua portuguesa. Revisto pelo Dr. Joaquim Ferreira. Porto: Editorial Domingos Barreira, s.d.

GASPARI, Elio. Gabeira deu uma aula ao comissariado petista. Folha de S. Paulo, São Paulo, 12 out. 2003. [Edição eletrônica.]

GÓNGORA, Luis de. Soledades. Madrid: Alianza Editorial, 1982. 
GUILLÉN, Jorge. Lenguaje poético: Góngora. In: Lenguaje y poesía: algunos casos españoles. Madrid: Alianza Editorial, 1983.

GUIRAUD, Pierre. La semántica. México: Fondo de Cultura Económica, 1992.

HOUAISS, Antônio. Elementos de bibliologia. Rio de Janeiro: Instituto Nacional do Livro, 1967. 2v.

HOUAISS, Antônio, VILLAR, Mauro de Salles. Dicionário Houaiss da Língua Portuguesa. Rio de Janeiro: Objetiva, 2001.

MACHADO, José Pedro. Dicionário etimológico da língua portuguesa. Lisboa: Livros Horizonte, 1987. 5v.

MATOS, Eusébio de. Sermão do mandato. Belo Horizonte: FALE/UFMG, 1999.

MOLIÈRE. Les fourberies de Scapin. Paris: Larousse, 1972. [Nouveaux Classiques Larousse]

MOLIÈRE. As artimanhas de Scapino. Trad. Carlos Drummond de Andrade. Rio de Janeiro: Ministério da Educação e Cultura, 1962.

OLIVEIRA, Manuel Botelho de. Música do Parnasso. Rio de Janeiro: Instituto Nacional do Livro, 1953. 2t.

PENA, Martins. O Cigano. In: Teatro de Martins Pena: comédias. Ed. crítica de Darcy Damasceno. Rio de Janeiro: Instituto Nacional do Livro, 1956. p.339-362.

RIBEIRO, João. Curiosidades verbais. 2.ed. Rio de Janeiro: São José, 1963.

RÓNAI, Paulo. A vida de Balzac. Rio de Janeiro: Ediouro, s.d.

SAUSSURE, Ferdinand de. Curso de lingüística geral. 9.ed. São Paulo: Cultrix, s.d. SPINA, Segismundo. Introdução. In: MELO, Dom Francisco Manuel de. A tuba de Calíope. São Paulo: Brasiliense, 1988. p.15-21.

SPINA, Segismundo. Introdução à edótica: crítica textual. 2.ed. São Paulo: Ars Poetica, 1994.

VENDRYES, J. El lenguaje: introducción lingüística a la historia. México: UTEHA, 1958.

\begin{abstract}
Based on an antithesis found in a poem by Eusébio de Matos, this paper analyzes the meanings of the verb "lograr" during the 17th century and in other centuries. The problem concerning the semantic field of this verb came up during the preparation of the edition of the work A Paixão de Cristo Senhor Nosso, which includes Matos' poem. This article also discusses aspects related to semantic changes and comments on the History of the Portuguese Language.
\end{abstract}

Key words: Brazilian Literature, Baroque Poetry, History of the Portuguese Language 
